\title{
私たちの行った高位脛骨骨切り術の検討
}

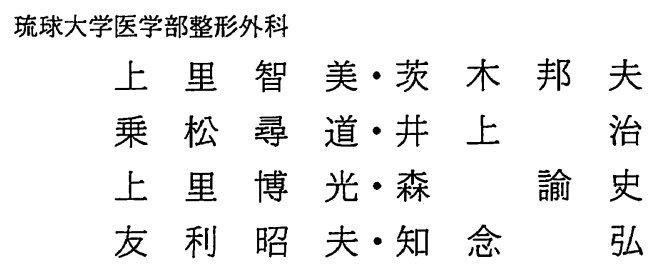

\section{A Follow-up Study of High Tibial Osteotomy}

by
Tomomi Uesato, Kunio Ibaraki, Hiromichi Norimatsu, Osamu Inoue, Hiromitsu Uesato, Satoshi Mori, Akio Tomori and Hiroshi Chinen

Department of Orthopedic Surgery, School of Medicine, University of the Ryukyus

We have experienced high tibial osteotomy in 18 osteoarthritic knees of 14 cases since 1982, using the blade plate introduced by Yokohama City University Medical School.

The short-term results were evaluated clinically and radiologically with an average period of 1 year and 5 months after the operation. An average score of clinical evaluation was $84 \%$ and the range of motion was improved remarkably at the time of follw-up. According to radiological examination, seven joints showed over-correction and 2 joints under-correction. Based on our experience we discussed the preoperative determination of correction angle.

\section{はじめに}

私たちは，内側型変形性滕関節症に対する高位脛 骨122)骨切り術に際し，従来，スティプルによる内固定 とシリンダーキャストによる外固定を併用する方法を 行っていたが, 昭和 57 年以降, 横浜市大式ひねりプレ 一トによる強固な内固定のみによる方法を行っている3). これは，ギプスによる外固定をまったく必要としない ため, 術後早期より届伸運動が可能となり, 術後拘縮 の合併率が少ない.

短期経過ではあるが，今回調查した術後成績をもと に, 術前の骨切り角度の決定法および後療法に関し若 干の考察と反省を加えて報告する4).

$$
\text { 対象 }
$$

昭和 57 年以降, 当科にてひねりプレートによる高位 脛骨骨切り術を行った症例は 14 例 18 関節, 年令は 32 オ〜 76 才, 平均 61 才で, 男 3 例 3 関節, 女 11 例 15 関
節である．全例内側型変形性膝関節症で，横浜市大式 のレ線による判定では，内側関節裂隙の閉鎖する Grade III 13 関節, 荷重面の摩耗する Grade IV 5 関節であっ た.

術前の片脚立位レ線像では，FTA 183 度〜195 度, 平均 188 度で, 荷重線は全例膝関節中心より内側を通 っていた．また，可動域は平均 118 度で，3 大学試案 による臨床機能評価は 33 点 69 点, 平均 47 点で, 疼 痛, 歩行能力に関しての評価が悪かった。術後経過期 間は 5 カ月〜 2 年 8 カ月で平均 1 年 5 カ月である.

$$
\text { 方法 }
$$

骨切り角度の決定には, 術前の片脚立位レ線像をも とに骨切り後の FTA が 170 度となるようにした。骨切 り角度は 10 度〜25 度で平均 19 度であった。

術式はオリジナル通り行い，全例に膝蓋大腿関節の 除圧および骨切り面の安定のため脛骨粗面の前方移動 を加えた。 
後療法は，術後数日より自動屆伸運動による可動域 改善や筋力強化の積極的リハビリ訓練を開始し, 1 ～ 2 週間で非荷重歩行， 6 週で部分荷重を開始し，骨瘜合 後全荷重歩行を行った.

$$
\text { 結果 }
$$

今回の調査時の滕関節の可動域はすべての症例で術 前と同じ，あるいはそれ以上に改善しており，平均で も術前 118 度が 131 度となっている，また， 3 大学試 案による評価も術前の 49 点から 84 点と改善し, 患者 自身も普段の日常生活での痛みが軽減し, 買い物など の行動範囲が広がったなどの印象を述べ，ほとんどの 症例で満足だという結果が得られた（表 1 ）.

しかし, 調査時の片脚立位レ線像によるFTAでは, 165 度以下の過度の外反を呈している症例が 6 例 7 関 節もあり,その荷重線は滕関節中心により $2 \mathrm{~cm}$ 以上外 側を通過していた。 また, 逆に 176 度以上の過小矯正 だと思われる症例が 1 例 2 関節あった(表 2 ). しかし, 現時点の短期間の術後経過では, 術後の矯正角度と術 後成績との相関関係を見出すことはできなかった.

また，調查時までに 5 例 7 関節に対し抜釘術を施行 しており，同時に関節鏡にて関節軟骨の状態を観察し ているが, 術前の軟骨と比べ, その修復が確認された 症例は 1 例 1 関節と少なく, 軟骨修復と成績との関係 も不明であった。観察は, 術後平均 1 年 2 カ月で行わ れた.

\section{考察}

私たちの行ったひねりプレートによる固定法では， 術後, 関節可動域の減少した症例はなく, むしろ著明 に改善していることは注目に值する。これは，術後 6 週間の免荷を行ったための除痛効果と強固な内固定の

表 1 術前 - 術後の可動域と機能評価 可動域

機能評価
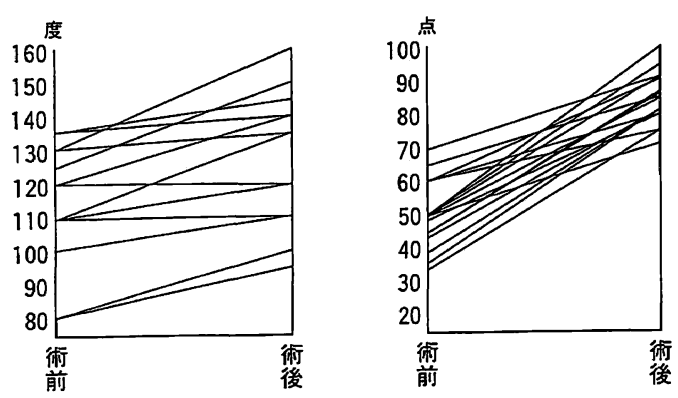

表 2 FTAの推移
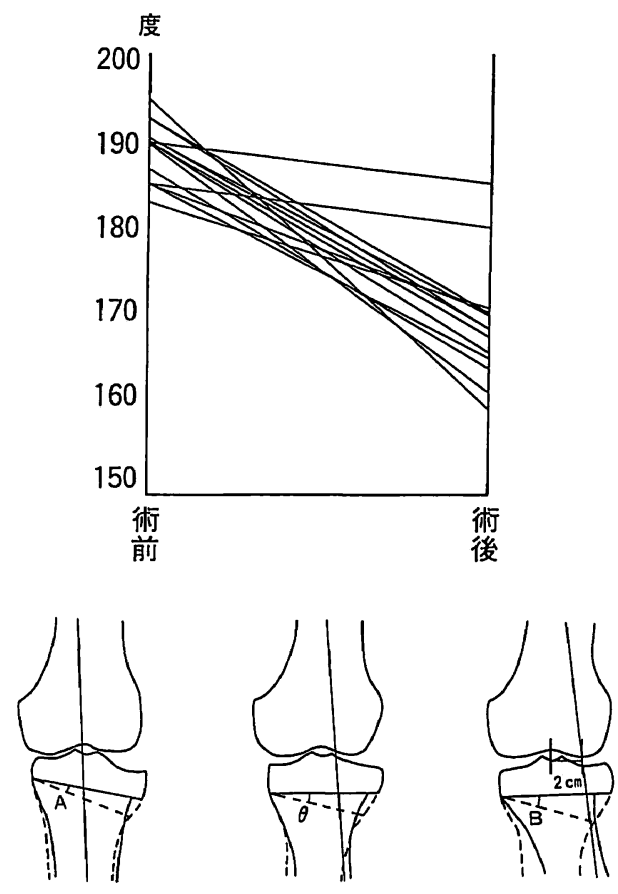

片脚立位での作図

実際の骨切り

強制外反での作図
1）軽度な内側動摇㮏

2) 高度な内側動摇䐂

もとにリハビリ訓練を積極的に行ったためだと思われ る. また, 外固定を使用しないため, 入浴, 用便など の基本的な日常生活動作が楽であり, 高令者の術後ケ アーも容易で, 術直後の患者の不満も少ないという利 点もある. しかし, 反面, 本法では, 骨痖合が得られ るまで本格的な荷重歩行を遅らせるという問題点もあ る. 私たちは, 早期の荷重歩行を必要とする症例に対 しては, 膝関節固定装具にての荷重歩行を行っている.

今回の術後結果からの反省点は, 過大矯正による FTA が 165 度以下で，かつ荷重線が滕関節中心より 2 $\mathrm{cm}$ 以上外側を通る例が 7 関節, 逆に過小矯正にて, 荷 重線が中心より内側を通る例が 2 関節生じたことであ る.

そこで私たちは, 骨切り角度の決め方として次の方 法を考案した. まず, 内側動摇性の少い症例に対して は, 片脚立位のレ線にて荷重線が, 中心を越える角度 
$\mathrm{A}$ を求め, 次に強制外反位のレ線にて荷重線が $2 \mathrm{~cm}$ 外 側を越える角度 Bを求める. 実際の骨切りは, その両 者の中間をとって, $\theta$ で行うと, 安定した外側の荷重面 が得られると考える. しかし, 症例の多くは, 内側の 動摇性が強いのでAの角度がBより大きくなる，この 場合, 私たちは, 荷重軸を外側へ移動させることを最 低条件と考えAの角度で骨切りを行うこととする。こ れで過小矯正は防げるが，過大矯正に関しては，レ線 撮影法などをもとに今後とも検討を加えてゆきたい. 今回の調查では, 過度の外反腺による不満や過小矯 正による術後の疼痛の持続などは少いが, 術後経過期 間が短いので，今後の注意深い経過観察を必要として いる.

$$
\text { ま と め }
$$

私たちは, 14 例 18 関節の内側型変形性膝関節症に対 し, 横浜市大式ひねりプレート使用による高位脛骨骨 切り術を施行した. 術後経過は平均 1 年 5 カ月である が, 3 大学試案による臨床機能評価が 47 点から 84 点
に改善された。

術後結果をもとに，骨切り角度の決定法に関し若干 の反省と考察を加えて報告した。

\section{参 考 文 献}

1) Coventry, M. B.: Uppertibial osteotomy for gonarthrosis, Orthop. Clin. North. Am., 10 : 191$210,1979$.

2) Insall, J. : High tibial osteotomy., J. Bone and Joint Surg., 56-A : 1397- 1405, 1974.

3）腰野富久: 変形性膝関節症の手術的治療. 日整会誌, $45: 1121-1133,1971$.

4）長野健治：変形性膝関節症に対する高位脛骨骨切り 術の成績. 整形・災害外科, $26: 473-480,1983$.

質 問福岡整形外科病院 小林 晶 屈角度が術後平均して不充分のように思うがどうか。

解 答

琉球大学 上里 博光

術前に拘縮の強い症例も多く, 術後改善はしたが, 著明な改善を示してない例がある。 